
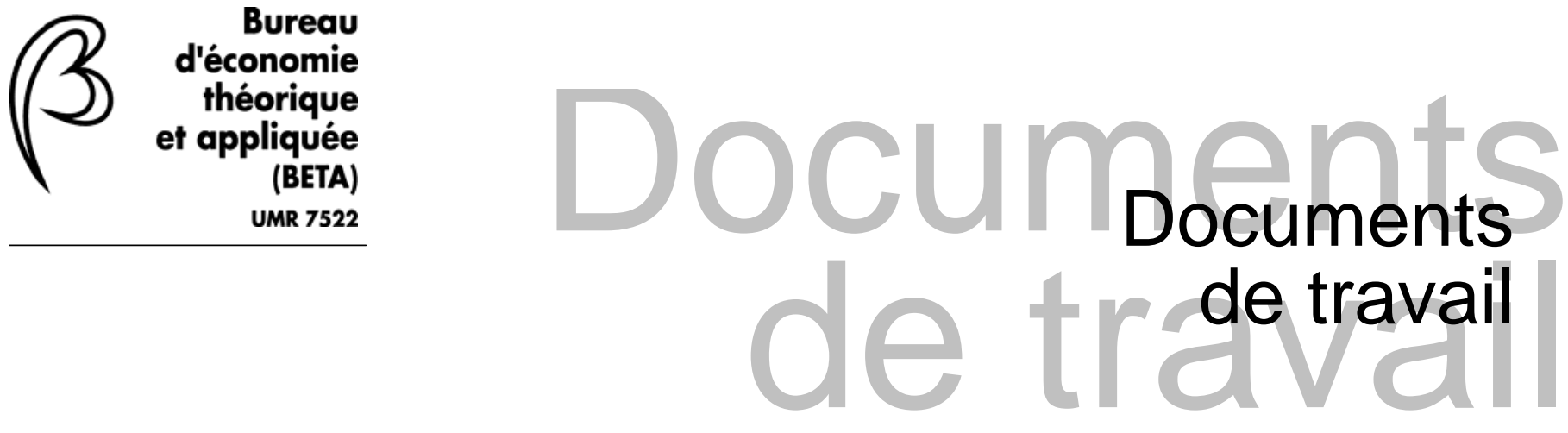

\title{
« Robust Control and Monetary Policy Delegation »
}

\section{Auteurs}

Giuseppe DIANA, Moïse SIDIROPOULOS

Document de travail $n^{\circ}$ 2006-26

Octobre 2006

Faculté des sciences économiques et de gestion

Pôle européen de gestion et d'économie (PEGE)

61 avenue de la Forêt Noire

F-67085 Strasbourg Cedex

Secrétariat du BETA

Christine Demange

Tél. : (33) 0390242069

Fax : (33) 0390242070 demange@cournot.u-strasbg.fr http://cournot.u-strasbg.fr/beta 


\title{
Robust Control and Monetary Policy Delegation
}

\author{
Giuseppe Diana and Moise Sidiropoulos
}

BETA-Theme, University Louis Pasteur of Strasbourg (France)

July 21,2006

\begin{abstract}
This paper adapts in a simple static context the Rogoff's (1985) analysis of monetary policy delegation to a conservative central banker to the robust control framework. In this framework, uncertainty means that policymakers are unsure about their model, in the sense that there is a group of approximate models that they also consider as possibly true, and their objective is to choose a rule that will work under a range of different model specifications. We find that robustness reveals the emergence of a precautionary behaviour in the case of unstructured model uncertainty, reducing thus government's willingness to delegate monetary policy to a conservative central banker.

Keywords : Robust control, Monetary policy delegation, Central bank conservativeness.

JEL classification : E52, E58

Corresponding author: diana@cournot.u-strasbg.fr (Giuseppe Diana)
\end{abstract}




\section{Introduction}

In a seminal paper Rogoff (1985) suggested that, by appointing a conservative central banker with a more important inflationary aversion than the whole society, social welfare could be improved with respect to discretionary equilibrium. This proposition, adopted by the majority of countries during the last two decades, reduces the inflation bias arising from discretionary monetary policies (Kydland and Prescott, 1977 and Barro and Gordon, 1983). Thus the choice of optimally inflationary aversion would find the socially best balance between the output stabilisation and prices in response to supply shocks hitting the economy.

However, in this framework policymakers are assumed to know the true model of the economy and observe accurately all relevant macroeconomic variables. Uncertainty arises from the unknown future realisations of the supply shocks, assumed to be modelled according to some stochastic process whose properties is known. Unfortunately, the reality is much more complex. The policymaker's choice is made in the fare of tremendous uncertainty about the true structure of the economy, the impact policy actions have on the economy, and even about the current state of the economy. This complexity means that a certain degree of subjectivity enters into the actual decision making when deciding upon optimal monetary policy. In other words, the policymaker is unsure about his model, in the sense that there is a group of approximate models that he also considers as possibly true.

This raises the question of how a monetary policy rule should be selected in the face of uncertainty about the correct model of the economy. In fact, solutions to the expected value problem by standard optimal control methods do not deliver the best average performance if they are applied to an incorrect model. Because uncertainty is pervasive, it is important to understand how alternative policies work when the policymaker employs a model of the economy that is incorrect in unknown ways. Therefore, the resulting problem is one of robust control, in the sense of Hansen and Sargent (2004), where the objective is to choose a rule that will work under a range of different model specifications. The notion that policy decisions may be more robust if based on systematically distorted model of the economy is a key implication of the recent research on robustness control or uncertainty aversion literature (Onatski and Williams, 2003; Giordani and Söderlind, 2004; Leitemo and Söderström, 2004; Walsh, 2004).

This paper adapts robust control approach to the problem of monetary policy delegation to a conservative central banker in a simple static context in order to illustrate the basic intuition behind this new approach to uncertainty. In this context, it is particular important to give an answer to the question whether model uncertainty can affect the government's optimal commitment to fight inflation, as well as his will to delegate the conduct of monetary policy to a conservative central banker. In this framework, we find that robustness of a monetary policy rule reveals the emergence of a precautionary behaviour in the case of policymaker's unstructured model uncertainty, reducing thus willingness to delegate monetary policy to a conservative central banker.

The rest of the paper is organised as follows. Section 2 sets up a one-period model 
of monetary policy. Section 3 de-rives the discretionary equilibrium under robust control. Section 4 derives the optimal degree of central banker conservativeness. Section 5 summarises the main conclusions.

\section{The model}

In this section, we apply the basic idea of robust control to a simple static model of monetary policy delegation originally developed in Rogoff (1985) in which policymaker sets inflation according to the following augmented Phillips curve:

$$
x=\pi^{e}-\pi+\epsilon+h
$$

where $x \equiv u-u^{*}$ is the gap between the unemployment rate $u$ and the natural rate of unemployment $u^{*}>0, \pi$ is the inflation rate, $\pi^{e}$ is the rationally expected inflation rate, $\epsilon$ is a random variable with mean zero and variance 1 , and $h$ is an additional deterministic disturbance component which introduce ambiguity of the model. The two disturbances terms and have different properties. The term $\epsilon$ is assumed to be a random error with a prior known stochastic properties, whilst $h$ represents in the spirit of robust control (Hansen and Sargent, 2004) a totally ambiguous model misspecification error, in the sense that the policymaker is not able to assign any prior probability distribution to $h$. The model with $h=0$ represents the reference model, while the models with $h \neq 0$ represent candidate models surrounding the reference model. The size of the distortion term $h$ must be bounded as the policymaker has some information on the process. Hence, we assume that the magnitude of the square of the specification error verifies:

$$
h^{2} \leq \eta^{2}
$$

where the parameter $\eta^{2}$ bounds the square of the government's specification error $h^{2}$. Restriction (2), together with equation (1), defines a set of models that the government considers as being possible outcomes in the sense that the policymaker does not know exactly the position of the Phillips curve in the space $\left(x, \pi^{e}-\pi\right)$.

The government's preferences are described by the following standard quadratic utility function:

$$
U_{s}=-\frac{1}{2}\left(u^{2}+\pi^{2}\right)
$$

where the government is assumed to stabilise unemployment $u$ and inflation $\pi$ around their target values, which are for simplicity fixed to zero. According to Rogoff (1985), monetary policy is delegated by the government to a "conservative" central banker, whose decision making problem is presented by the following quadratic utility function:

$$
U_{c b}=-\frac{1}{2}\left[u^{2}+(1+\phi) \pi^{2}\right]
$$


where $\phi>0$ is the degree of conservativeness chosen by the government and is the optimal extra (relative) weight the central banker sets on inflation stabilisation ${ }^{1}$.

\section{Discretion under robust control}

According to the robust control approach, in order to hedge against the model ambiguity, the policymaker makes a particular subjective assessment of $h$. In other words, he chooses the worst case $(h \neq 0)$ at any given $\pi^{e}$ and then designs corresponding monetary policy rule $\pi$ which maximises the utility at given $h$. In order to introduce such subjective assessment of $h$ into the decision making problem, we replace the standard quadratic utility function (4) by an "uncertainty aversion" utility function and we seek a solution to the following problem:

$$
\max _{\pi} \min _{h} U_{\theta}=-\frac{1}{2}\left[u^{2}+(1+\phi) \pi^{2}\right]+\frac{\theta}{2} h^{2}
$$

The design of a robust policy rule becomes now a max-min problem, where the optimal level of inflation is found by maximizing $U_{\theta}$, with $h$ being chosen to minimize $U_{\theta}$ subject to the linear constraint (1). $\theta$ is a fixed penalty parameter which reflects both the government and the central banker's desired degree of robustness. In other words, we assume that the government and the central banker share the same doubts about the accuracy of the model of the economy. $\theta>1$ can be interpreted as a Lagrangian multiplier on constraint (2). The value $\theta=1$ is the breakdown point to be discussed later. The value for $\theta$ would be endogenous in the constrained Lagrangian, and it would be associated to the specific $\eta$ value used in the constraint (2). The way the problem is written here, $\theta$ is chosen directly and the constraint is adapted accordingly. Note also that larger values of $\theta$ imply smaller sets of models so that $\theta$ is an indicator of the precautionary behaviour of the authorities. In other words, the more $\theta$ is close to one, the more the government is insuring about the accuracy of the model it uses. In the opposite case, as $\theta \rightarrow+\infty$, the government believes that its model is a good approximation of the true model of the economy. In the limit case where $\theta=+\infty$, there is no misspecification and the government is convinced that the model it uses is the true one. From the first order conditions for $\pi$ and $h$ in the problem (5), we obtain respectively the reaction functions:

$$
\begin{aligned}
& \pi(\theta)=\frac{\theta}{\theta+(1+\phi)(\theta-1)}\left(u^{*}+\epsilon+\pi^{e}\right) \\
& h(\theta)=\frac{(1+\phi)}{\theta+(1+\phi)(\theta-1)}\left(u^{*}+\epsilon+\pi^{e}\right)
\end{aligned}
$$

where $\pi(\theta)$ gives the central banker's (robust) best reaction function for setting $\pi$ as a function of $\pi^{e}$, while $h(\theta)$ determines the worst case model, given $\pi^{e}$ and the central banker's setting $\pi(\theta)$. Then, using equation (6) and assuming rational expectations of the private sector $\left(\pi^{e}=E \pi\right)$ yields:

\footnotetext{
${ }^{1}$ Rogoff (1985) demonstrates that the optimal extra (relative) weight the central banker sets on inflation is finite and strictly positive.
} 


$$
\pi^{e}(\theta)=\frac{\theta u^{*}}{(1+\phi)(\theta-1)}
$$

By substituting equation (8) into equation (6), the time-consistent rational expectations equilibrium inflation rate is:

$$
\pi(\theta)=\frac{\theta u^{*}}{(1+\phi)(\theta-1)}+\frac{\theta \epsilon}{\theta+(1+\phi)(\theta-1)}
$$

From equation (9), it is clear that as $\theta \rightarrow 1$, the model breaks down as the equilibrium inflation rate tends to infinity. Finally, substituting equations (7), (8) and (9) into equation (1), we obtain the equilibrium rate of unemployment:

$$
u(\theta)=\frac{\theta u^{*}}{(\theta-1)}+\frac{\theta(1+\phi) \epsilon}{\theta+(1+\phi)(\theta-1)}
$$

Using equations (9) and (10), we can see that when $\theta \rightarrow+\infty$ there is no concern for model misspecification as $h(\infty)=0$ and thus the standard rational expectation model arises. The equilibrium inflation rate and unemployment gap are given by

$$
\begin{gathered}
\pi(\infty)=\frac{u^{*}}{(1+\phi)}+\frac{\epsilon}{1+(1+\phi)} \\
u(\infty)=u^{*}+\frac{(1+\phi) \epsilon}{1+(1+\phi)}
\end{gathered}
$$

Using equations (9) to (12), we establish the following proposition:

Proposition 1 If the approximating model is true (i.e., $\theta=+\infty$, and therefore $h(\infty)=0)$, so that the policymaker's concern about misspecification is misplaced, the central banker sets both inflation and unemployment higher than if he knew the model for sure. In other words, when the approximating model is correct, robust policies sacrifice macroeconomic performance.

Proof. This result straightforwardly follows from the respective comparison of equations (9) and (11) and equations (10) and (12).

However, it can be easily shown that as the specification error increases (i.e., as the parameter $\theta$ decreases) the deterioration of the macroeconomic performances are lower under the robust policy (see also Hansen and Sargent, 2004, chap. 5).

\section{The optimal conservativeness}

We now consider the government's optimal appointment of a conservative central banker. As the government chooses optimally the central banker, $\phi$ must be solved endogenously in order to maximise the government's expected utility. Our objective is to analyse how the precautionary behaviour of the government (captured by $\theta$ ) affects the optimal choice about the characteristics of the central banker (i.e., his 
degree of conservativeness $\phi$ ). Thus, using equations (9) and (10) into the government utility function (3), we derive the govern-ment's expected utility as a function of $\phi$ :

$$
E\left(U_{s}\right)=-\frac{1}{2} \theta^{2}\left[\frac{1+(1+\phi)^{2}\left(u^{*}\right)^{2}}{(1+\phi)^{2}(\theta-1)^{2}}+\frac{1+(1+\phi)^{2} \epsilon}{[\theta+(1+\phi)(\theta-1)]^{2}}\right]
$$

Then we derive equation (13) with respect to $\phi$ and we obtain the following firstorder condition :

$$
\frac{\partial E\left(U_{s}\right)}{\partial \phi}=0 \Rightarrow f(\phi ; \theta)=\frac{(1+\theta \phi)(1+\phi)^{3}(\theta-1)^{2}}{[\theta+(1+\phi)(\theta-1)]^{2}}-\left(u^{*}\right)^{2}=0
$$

Using equation (14), we establish the following proposition.

Proposition 2 The more government desires a robust monetary policy rule suitable to the uncertainty about the true structure of the economy, the less he needs to appoint a conservative central banker with a high degree of inflationary aversion.

Proof. From equation (14) and remembering that $\theta>1$, we can write:

$$
\frac{\partial f(\phi ; \theta)}{\partial \phi}=\frac{\theta(1+\phi)^{2}(\theta-1)^{2}\left[\theta(1+\phi)+3(1+\theta \phi)+(1+\phi)^{2}(\theta-1)\right]}{[\theta+(1+\phi)(\theta-1)]^{4}}>0
$$

and

$$
\begin{gathered}
\frac{\partial f(\phi ; \theta)}{\partial \theta}=-\frac{(1+\phi)^{3}(\theta-1)\left[(2+\phi)^{2}(\theta-1)-2(1+\phi)\right]}{[\theta+(1+\phi)(\theta-1)]^{4}}<0 \\
\text { if } \theta>1+\frac{2(1+\phi)}{(2+\phi)^{2}}
\end{gathered}
$$

Note that inequality (16) holds only if condition (17) is verified. However, condition (17) is not restrictive since it is verified as soon as $\theta>1.5$. In fact, as $\phi>0$ it is obvious that $2(1+\phi) /(2+\phi)^{2} \leq 0.5$. For example if $\phi=1$, condition (17) becomes $\theta>1.444$ and if $\phi=2$, condition (17)becomes $\theta>1.375$. In other words, more the central banker is independent and conservative and more the condition (17) can be verified. Applying the implicit function rule, we obtain :

$$
\frac{\partial \phi}{\partial \theta}=-\frac{\partial f(\phi ; \theta) / \partial \theta}{\partial f(\phi ; \theta) / \partial \phi}>0
$$

According to the Proposition 2, the government's robust choice of $\phi$ reveals the emergence of a precautionary behaviour in the case of uncertainty about the true structure of the economy, reducing its willingness to delegate monetary policy to a "conservative" central banker. In other words, the more uncertain the government's model is, the more reluctant the government should be to appoint a conservative 
central banker. The intuition behind this proposition is that, as the structure of the economy is uncertain, it becomes optimal for the government to accept a central banker characterised by a low degree of conservativeness in order to implement a more flexible monetary policy, which will work well over a larger set of possible alternative models.

\section{Conclusion}

This paper adapts the robust control approach, in the sense of Hansen and Sargent (2004), to the Rogoff's (1985) seminal analysis of monetary policy delegation to a conservative central banker, when there is misspecification uncertainties about the model of the economy. We show that the government's robust choice reveals the emergence of a precautionary behaviour in the case of uncertainty about the true structure of the economy, reducing its willingness to delegate monetary policy to a conservative central banker with a high degree of inflation aversion. The intuition behind this result is that it becomes optimal to appoint a central banker with a low degree of conservativeness in order to implement a flexible monetary policy. 


\section{References}

[1] Barro, R. and Gordon, D. (1983) A Positive Theory of Monetary Policy in a Natural Rate Model. Journal of Political Economy, 91, 589-610.

[2] Hansen, L. P. and Sargent, T. J. (2004), Misspecification in RecursiveMacroeconomic Theory. Book manuscript, University of Chicago and NewYork University.

[3] Kydland, F. and Prescott E. (1977) Rules Rather than Discretion: the Inconsistency of Optimal Plans. Journal of Political Economy, 85, 473-491.

[4] Leitemo, K and Söderström, U (2004) Robust monetary policy in a small open economy. Manuscript, Norwegian School of Management andUniversità Bocconi.

[5] Rogoff, K., 1985, The Optimal Degree of Commitment to an Intermediate Monetary Target. Quarterly Journal of Eco-nomics, 100, 1169-1189.

[6] Giordani, P and Söderlind, P (2004) Solution of macromodels withHansenSargent robust policies: Some extensions. Journal of Economic Dynamics and Control, 28 (12), 2367-2397.

[7] Onatski, A and Williams, N (2003) Modeling model uncertainty. Journal of the European Economic Association, 1 (5), 1087-1122.

[8] Walsh, C (2004) Robust optimal instrument rules and robust control: An equivalence result. Manuscript, University of California, Santa Cruz. 


\section{Documents de travail du BETA}

2000-01 Hétérogénéité de travailleurs, dualisme et salaire d'efficience. Francesco DE PALMA, janvier 2000.

2000-02 An Algebraic Index Theorem for Non-smooth Economies. Gaël GIRAUD, janvier 2000.

2000-03 Wage Indexation, Central Bank Independence and the Cost of Disinflation. Giuseppe DIANA, janvier 2000.

2000-04 Une analyse cognitive du concept de « vision entrepreneuriale ». Frédéric CRÉPLET, Babak MEHMANPAZIR, février 2000.

2000-05 Common knowledge and consensus with noisy communication. Frédéric K৫SSLER, mars 2000.

2000-06 Sunspots and Incomplete Markets with Real Assets. Nadjette LAGUÉCIR, avril 2000.

2000-07 Common Knowledge and Interactive Behaviors : A Survey. Frédéric KCESSLER, mai 2000.

2000-08 Knowledge and Expertise : Toward a Cognitive and Organisational Duality of the Firm. Frédéric CRÉPLET, Olivier DUPOUËT, Francis KERN, Francis MUNIER, mai 2000.

2000-09 Tie-breaking Rules and Informational Cascades : A Note. Frédéric KESSLER, Anthony ZIEGELMEYER, juin 2000.

2000-10 SPQR : the Four Approaches to Origin-Destination Matrix Estimation for Consideration by the MYSTIC Research Consortium.

Marc GAUDRY, juillet 2000.

2000-11 SNUS-2.5, a Multimoment Analysis of Road Demand, Accidents and their Severity in Germany, 1968-1989.

Ulrich BLUM, Marc GAUDRY, juillet 2000.

2000-12 On the Inconsistency of the Ordinary Least Squares Estimator for Spatial Autoregressive Processes.

Théophile AZOMAHOU, Agénor LAHATTE, septembre 2000.

2000-13 Turning Box-Cox including Quadratic Forms in Regression. Marc GAUDRY, Ulrich BLUM, Tran LIEM, septembre 2000.

2000-14 Pour une approche dialogique du rôle de l'entrepreneur/managerdans l'évolution des PME : I'ISO comme révélateur ...

Frédéric CRÉPLET, Blandine LANOUX, septembre 2000.

2000-15 Diversity of innovative strategy as a source of technological performance.

Patrick LLERENA, Vanessa OLTRA, octobre 2000.

2000-16 Can we consider the policy instruments as cyclical substitutes ?

Sylvie DUCHASSAING, Laurent GAGNOL, décembre 2000. 
2001-01 Economic growth and CO2 emissions : a nonparametric approach.

Théophile AZOMAHOU, Phu NGUYEN VAN, janvier 2001.

2001-02 Distributions supporting the first-order approach to principal-agent problems.

Sandrine SPÆETER, février 2001.

2001-03 Développement durable et Rapports Nord-Sud dans un Modèle à Générations Imbriquées : interroger le futur pour éclairer le présent.

Alban VERCHÈRE, février 2001.

2001-04 Modeling Behavioral Heterogeneity in Demand Theory.

Isabelle MARET, mars 2001.

2001-05 Efficient estimation of spatial autoregressive models.

Théophile AZOMAHOU, mars 2001.

2001-06 Un modèle de stratégie individuelle de primo-insertion professionnelle.

Guy TCHIBOZO, mars 2001.

2001-07 Endogenous Fluctuations and Public Services in a Simple OLG Economy. Thomas SEEGMULLER, avril 2001.

2001-08 Behavioral Heterogeneity in Large Economies.

Gaël GIRAUD, Isabelle MARET, avril 2001.

2001-09 GMM Estimation of Lattice Models Using Panel Data : Application. Théophile AZOMAHOU, avril 2001.

2001-10 Dépendance spatiale sur données de panel : application à la relation Brevets-R\&D au niveau régional.

Jalal EL OUARDIGHI, avril 2001.

2001-11 Impact économique régional d'un pôle universitaire : application au cas strasbourgeois.

Laurent GAGNOL, Jean-Alain HÉRAUD, mai 2001.

2001-12 Diversity of innovative strategy as a source of technological performance.

Patrick LLERENA, Vanessa OLTRA, mai 2001.

2001-13 La capacité d'innovation dans les regions de l'Union Européenne.

Jalal EL OUARDIGHI, juin 2001.

2001-14 Persuasion Games with Higher Order Uncertainty.

Frédéric K৫SSLER, juin 2001.

2001-15 Analyse empirique des fonctions de production de Bosnie-Herzégovine sur la période 1952-1989.

Rabija SOMUN, juillet 2001.

2001-16 The Performance of German Firms in the Business-Related Service Sectors : a Dynamic Analysis.

Phu NGUYEN VAN, Ulrich KAISER, François LAISNEY, juillet 2001.

2001-17 Why Central Bank Independence is high and Wage indexation is low.

Giuseppe DIANA, septembre 2001.

2001-18 Le mélange des ethnies dans les PME camerounaises: l'émergence d'un modèle d'organisation du travail.

Raphaël NKAKLEU, octobre 2001. 
2001-19 Les déterminants de la GRH des PME camerounaises.

Raphaël NK AKLEU, octobre 2001.

2001-20 Profils d'identité des dirigeants et stratégies de financement dans les PME camerounaises. Raphaël NKAKLEU, octobre 2001.

2001-21 Concurrence Imparfaite, Variabilité du Taux de Marge et Fluctuations Endogènes.

Thomas SEEGMULLER, novembre 2001.

2001-22 Determinants of Environmental and Economic Performance of Firms : An Empirical Analysis of the European Paper Industry.

Théophile AZOMAHOU, Phu NGUYEN VAN et Marcus WAGNER, novembre 2001.

2001-23 The policy mix in a monetary union under alternative policy institutions and asymmetries. Laurent GAGNOL et Moïse SIDIROPOULOS, décembre 2001.

2001-24 Restrictions on the Autoregressive Parameters of Share Systems with Spatial Dependence. Agénor LAHATTE, décembre 2001.

2002-01 Strategic Knowledge Sharing in Bayesian Games : A General Model. Frédéric KESSLER, janvier 2002.

2002-02 Strategic Knowledge Sharing in Bayesian Games : Applications.

Frédéric KESSLER, janvier 2002.

2002-03 Partial Certifiability and Information Precision in a Cournot Game. Frédéric KESSLER, janvier 2002.

2002-04 Behavioral Heterogeneity in Large Economies.

Gaël GIRAUD, Isabelle MARET, janvier 2002.

(Version remaniée du Document de Travail n²001-08, avril 2001).

2002-05 Modeling Behavioral Heterogeneity in Demand Theory.

Isabelle MARET, janvier 2002.

(Version remaniée du Document de Travail n²001-04, mars 2001).

2002-06 Déforestation, croissance économique et population : une étude sur données de panel. Phu NGUYEN VAN, Théophile AZOMAHOU, janvier 2002.

2002-07 Theories of behavior in principal-agent relationships with hidden action.

Claudia KESER, Marc WILLINGER, janvier 2002.

2002-08 Principe de précaution et comportements préventifs des firmes face aux risques environnementaux.

Sandrine SPÆTER, janvier 2002.

2002-09 Endogenous Population and Environmental Quality.

Phu NGUYEN VAN, janvier 2002.

2002-10 Dualité cognitive et organisationnelle de la firme au travers du concept de communauté. Frédéric CRÉPLET, Olivier DUPOUËT, Francis KERN, Francis MUNIER, février 2002.

2002-11 Comment évaluer l'amélioration du bien-être individuel issue d'une modification de la qualité du service d'élimination des déchets ménagers?

Valentine HEINTZ, février 2002. 
2002-12 The Favorite-Longshot Bias in Sequential Parimutuel Betting with Non-Expected Utility Players.

Frédéric K৫SSLER, Anthony ZIEGELMEYER, Marie-Hélène BROIHANNE, février 2002.

2002-13 La sensibilité aux conditions initiales dans les processus individuels de primo-insertion professionnelle : critère et enjeux.

Guy TCHIBOZO, février 2002.

2002-14 Improving the Prevention of Environmental Risks with Convertible Bonds.

André SCHMITT, Sandrine SPAETER, mai 2002.

2002-15 L'altruisme intergénérationnel comme fondement commun de la courbe environnementale à la Kuznets et du développement durable.

Alban VERCHÈRE, mai 2002.

2002-16 Aléa moral et politiques d'audit optimales dans le cadre de la pollution d'origine agricole de l'eau.

Sandrine SPÆETER, Alban VERCHÈRE, juin 2002.

2002-17 Parimutuel Betting under Asymmetric Information.

Frédéric KESSLER, Anthony ZIEGELMEYER, juin 2002.

2002-18 Pollution as a source of endogenous fluctuations and periodic welfare inequality in OLG economies.

Thomas SEEGMULLER, Alban VERCHÈRE, juin 2002.

2002-19 La demande de grosses coupures et l'économie souterraine.

Gilbert KENIG, juillet 2002.

2002-20 Efficiency of Nonpoint Source Pollution Instruments with Externality Among Polluters : An Experimental Study.

François COCHARD, Marc WILLINGER, Anastasios XEPAPADEAS, juillet 2002.

2002-21 Taille optimale dans l'industrie du séchage du bois et avantage compétitif du bois-énergie : une modélisation microéconomique.

Alexandre SOKIC, octobre 2002.

2002-22 Modelling Behavioral Heterogeneity.

Gaël GIRAUD, Isabelle MARET, novembre 2002.

2002-23 Le changement organisationnel en PME : quels acteurs pour quels apprentissages ?

Blandine LANOUX, novembre 2002.

2002-24 TECHNOLOGY POLICY AND COOPERATION : An analytical framework for a paradigmatic approach.

Patrick LLERENA, Mireille MATT, novembre 2002.

2003-01 Peut-on parler de délégation dans les PME camerounaises ?

Raphaël NKAKLEU, mars 2003.

2003-02 L'identité organisationnelle et création du capital social: la tontine d'entreprise comme facteur déclenchant dans le contexte africain.

Raphaël NKAKLEU, avril 2003.

2003-03 A semiparametric analysis of determinants of protected area.

Phu NGUYEN VAN, avril 2003. 
2003-04 Strategic Market Games with a Finite Horizon and Incomplete Markets.

Gaël GIRAUD et Sonia WEYERS, avril 2003.

2003-05 Exact Homothetic or Cobb-Douglas Behavior Through Aggregation.

Gaël GIRAUD et John K.-H. QUAH, juin 2003.

2003-06 Relativité de la satisfaction dans la vie : une étude sur données de panel.

Théophile AZOMAHOU, Phu NGUYEN VAN, Thi Kim Cuong PHAM, juin 2003.

2003-07 A model of the anchoring effect in dichotomous choice valuation with follow-up. Sandra LECHNER, Anne ROZAN, François LAISNEY, juillet 2003.

2003-08 Central Bank Independence, Speed of Disinflation and the Sacrifice Ratio. Giuseppe DIANA, Moïse SIDIROPOULOS, juillet 2003.

2003-09 Patents versus ex-post rewards : a new look.

Julien PÉNIN, juillet 2003.

2003-10 Endogenous Spillovers under Cournot Rivalry and Co-opetitive Behaviors. Isabelle MARET, août 2003.

2003-11 Les propriétés incitatives de l'effet Saint Matthieu dans la compétition académique.

Nicolas CARAYOL, septembre 2003.

2003-12 The 'probleme of problem choice': A model of sequential knowledge production within scientific communities.

Nicolas CARAYOL, Jean-Michel DALLE, septembre 2003.

2003-13 Distribution Dynamics of $\mathrm{CO}_{2}$ Emissions.

Phu NGUYEN VAN, décembre 2003.

2004-01 Utilité relative, politique publique et croissance économique.

Thi Kim Cuong PHAM, janvier 2004.

2004-02 Le management des grands projets de haute technologie vu au travers de la coordination des compétences.

Christophe BELLEVAL, janvier 2004.

2004-03 Pour une approche dialogique du rôle de l'entrepreneur/manager dans l'évolution des PME : I'ISO comme révélateur ...

Frédéric CRÉPLET, Blandine LANOUX, février 2004.

2004-04 Consistent Collusion-Proofness and Correlation in Exchange Economies.

Gaël GIRAUD, Céline ROCHON, février 2004.

2004-05 Generic Efficiency and Collusion-Proofness in Exchange Economies.

Gaël GIRAUD, Céline ROCHON, février 2004.

2004-06 Dualité cognitive et organisationnelle de la firme fondée sur les interactions entre les communautés épistémiques et les communautés de pratique..

Frédéric CRÉPLET, Olivier DUPOUËT, Francis KERN, Francis MUNIER, février 2004.

2004-07 Les Portails d'entreprise: une réponse aux dimensions de l'entreprise «processeur de connaissances ».

Frédéric CRÉPLET, février 2004. 
2004-08 Cumulative Causation and Evolutionary Micro-Founded Technical Change: A Growth Model with Integrated Economies.

Patrick LLERENA, André LORENTZ, février 2004.

2004-09 Les CIFRE : un outil de médiation entre les laboratoires de recherche universitaire et les entreprises.

Rachel LÉVY, avril 2004.

2004-10 On Taxation Pass-Through for a Monopoly Firm.

Rabah AMIR, Isabelle MARET, Michael TROGE, mai 2004.

2004-11 Wealth distribution, endogenous fiscal policy and growth : status-seeking implications.

Thi Kim Cuong PHAM, juin 2004.

2004-12 Semiparametric Analysis of the Regional Convergence Process.

Théophile AZOMAHOU, Jalal EL OUARDIGHI, Phu NGUYEN VAN, Thi Kim Cuong PHAM, Juillet 2004.

2004-13 Les hypothèses de rationalité de l'économie évolutionniste. Morad DIANI, septembre 2004.

2004-14 Insurance and Financial Hedging of Oil Pollution Risks.

André SCHMITT, Sandrine SPAETER, septembre 2004.

2004-15 Altruisme intergénérationnel, développement durable et équité intergénérationnelle en présence d'agents hétérogènes.

Alban VERCHĖRE, octobre 2004.

2004-16 Du paradoxe libéral-parétien à un concept de métaclassement des préférences.

Herrade IGERSHEIM, novembre 2004.

2004-17 Why do Academic Scientists Engage in Interdisciplinary Research ?

Nicolas CARAYOL, Thuc Uyen NGUYEN THI, décembre 2004.

2005-01 Les collaborations Université Entreprises dans une perspective organisationnelle et cognitive.

Frédéric CRÉPLET, Francis KERN, Véronique SCHAEFFER, janvier 2005.

2005-02 The Exact Insensitivity of Market Budget Shares and the 'Balancing Effect'.

Gaël GIRAUD, Isabelle MARET, janvier 2005.

2005-03 Les modèles de type Mundell-Fleming revisités.

Gilbert KOENIG, janvier 2005.

2005-04 L'État et la cellule familiale sont-ils substituables dans la prise en charge du chômage en Europe ? Une comparaison basée sur le panel européen.

Olivia ECKERT-JAFFE, Isabelle TERRAZ, mars 2005.

2005-05 Environment in an Overlapping Generations Economy with Endogenous Labor Supply : a Dynamic Analysis.

Thomas SEEGMULLER, Alban VERCHÈRE, mars 2005.

2005-06 Is Monetary Union Necessarily Counterproductive?

Giuseppe DIANA, Blandine ZIMMER, mars 2005.

2005-07 Factors Affecting University-Industry R\&D Collaboration : The importance of screening and signalling.

Roberto FONTANA, Aldo GEUNA, Mireille MATT, avril 2005. 
2005-08 Madison-Strasbourg, une analyse comparative de l'enseignement supérieur et de la recherche en France et aux États-Unis à travers l'exemple de deux campus.

Laurent BUISSON, mai 2005.

2005-09 Coordination des négociations salariales en UEM : un rôle majeur pour la BCE.

Blandine ZIMMER, mai 2005.

2005-10 Open knowledge disclosure, incomplete information and collective innovations.

Julien PÉNIN, mai 2005.

2005-11 Science-Technology-Industry Links and the 'European Paradox': Some Notes on the Dynamics of Scientific and Technological Research in Europe.

Giovanni DOSI, Patrick LLERENA, Mauro SYLOS LABINI, juillet 2005.

2005-12 Hedging Strategies and the Financing of the 1992 International Oil Pollution Compensation Fund.

André SCHMITT, Sandrine SPAETER, novembre 2005.

2005-13 Faire émerger la coopération internationale: une approche expérimentale comparée du bilatéralisme et du multilatéralisme.

Stéphane BERTRAND, Kene BOUN MY, Alban VERCHÈRE, novembre 2005.

2005-14 Segregation in Networks.

Giorgio FAGIOLO, Marco VALENTE, Nicolaas J. VRIEND, décembre 2005.

2006-01 Demand and Technology Determinants of Structural Change and Tertiarisation : An InputOutput Structural Decomposition Analysis for four OECD Countries.

Maria SAVONA, André LORENTZ, janvier 2006.

2006-02 A strategic model of complex networks formation.

Nicolas CARAYOL, Pascale ROUX, janvier 2006.

2006-03 Coordination failures in network formation.

Nicolas CARAYOL, Pascale ROUX, Murat YILDIZOGLU, janvier 2006.

2006-04 Real Options Theory for Lawmaking.

Marie OBIDZINSKI, Bruno DEFFAINS, août 2006.

2006-05 Ressources, compétences et stratégie de la firme : Une discussion de l'opposition entre la vision Porterienne et la vision fondée sur les compétences.

Fernand AMESSE, Arman AVADIKYAN, Patrick COHENDET, janvier 2006.

2006-06 Knowledge Integration and Network Formation.

Müge OZMAN, janvier 2006.

2006-07 Networks and Innovation : A Survey of Empirical Literature.

Müge OZMAN, février 2006.

2006-08 A.K. Sen et J.E. Roemer : une même approche de la responsabilité ? Herrade IGERSHEIM, mars 2006.

2006-09 Efficiency and coordination of fiscal policy in open economies.

Gilbert KOENIG, Irem ZEYNELOGLU, avril 2006.

2006-10 Partial Likelihood Estimation of a Cox Model With Random Effects : an EM Algorithm Based on Penalized Likelihood.

Guillaume HORNY, avril 2006. 
2006-11 Uncertainty of Law and the Legal Process.

Giuseppe DARI-MATTIACCI, Bruno DEFFAINS, avril 2006.

2006-12 Customary versus Technological Advancement Tests.

Bruno DEFFAINS, Dominique DEMOUGIN, avril 2006.

2006-13 Institutional Competition, Political Process and Holdup.

Bruno DEFFAINS, Dominique DEMOUGIN, avril 2006.

2006-14 How does leadership support the activity of communities of practice ?

Paul MULLER, avril 2006.

2006-15 Do academic laboratories correspond to scientific communities ? Evidence from a large European university.

Rachel LÉVY, Paul MULLER, mai 2006.

2006-16 Knowledge flows and the geography of networks. A strategic model of small worlds formation.

Nicolas CARAYOL, Pascale ROUX, mai 2006.

2006-17 A Further Look into the Demography-based GDP Forecasting Method.

Tapas K. MISHRA, juin 2006.

2006-18 A regional typology of innovation capacities in new member states and candidate countries. Emmanuel MULLER, Arlette JAPPE, Jean-Alain HÉRAUD, Andrea ZENKER, juillet 2006.

2006-19 Convergence des contributions aux inégalités de richesse dans le développement des pays européens.

Jalal EL OUARDIGHI, Rabiji SOMUN-KAPETANOVIC, septembre 2006.

2006-20 Channel Performance and Incentives for Retail Cost Misrepresentation.

Rabah AMIR, Thierry LEIBER, Isabelle MARET, septembre 2006.

2006-21 Entrepreneurship in biotechnology: The case of four start-ups in the Upper-Rhine Biovalley.

Antoine BURETH, Julien PÉNIN, Sandrine WOLFF, septembre 2006.

2006-22 Does Model Uncertainty Lead to Less Central Bank Transparency?

Li QIN, Elefterios SPYROMITROS, Moïse SIDIROPOULOS, octobre 2006.

2006-23 Enveloppe Soleau et droit de possession antérieure : Définition et analyse économique. Julien PÉNIN, octobre 2006.

2006-24 Le territoire français en tant que Système Régional d'Innovation.

Rachel LEVY, Raymond WOESSNER, octobre 2006.

2006-25 Fiscal Policy in a Monetary Union Under Alternative Labour-Market Structures. Moïse SIDIROPOULOS, Eleftherios SPYROMITROS, octobre 2006.

2006-26 Robust Control and Monetary Policy Delegation.

Giuseppe DIANA, Moïse SIDIROPOULOS, octobre 2006.

La présente liste ne comprend que les Documents de Travail publiés à partir du $1^{\mathrm{er}}$ janvier 2000. La liste complète peut être donnée sur demande.

This list contains the Working Paper writen after January 2000, 1rst. The complet list is available upon request. 